\title{
Process Engineering Accelerating an Economic Industrialization Towards a Bio-Based World
}

\author{
Lukas Uhlenbrock, Reinhard Ditz and Jochen Strube *
}

Institute for Separation and Process Technology, Clausthal University of Technology, 38678 Clausthal-Zellerfeld, Germany; uhlenbrock@itv.tu-clausthal.de (L.U.); ditz@itv.tu-clausthal.de (R.D.)

* Correspondence: strube@itv.tu-clausthal.de; Tel.: +49-5323-72-2355

Academic Editor: Farid Chemat

Received: 18 March 2019; Accepted: 10 May 2019; Published: 14 May 2019

\begin{abstract}
The transition towards a bio-based world is a challenging undertaking. This perspective paper, from an engineering point of view, aims to provide an overview of existing projects and academic disciplines highlighting the potential benefit of increased interdisciplinary exchanges. Furthermore, the current utilization of biomass to produce biogas is discussed, including an economic assessment, showing the need for new strategies of biomass valorization. One solution could be the development of separation processes for the isolation of secondary plant metabolites, which have been especially valuable for pharmaceutical applications, e.g., taxotere ${ }^{\circledR}$ and artemisinin. The economic feasibility is demonstrated in a case study, evaluating the purification potential of curcuminoids from Curcuma longa L. Subsequently, the conclusion discusses the limitations of large-scale industrial applications and the need for new separation techniques as a step towards a bio-based world.
\end{abstract}

Keywords: bioeconomy; secondary metabolites; purification strategies; bio-based world; waste valorization; resource-efficient production

\section{Introduction}

The reduction of the industries need for fossil resources is discussed in Germany and many other regions worldwide. Geopolitical considerations may provide additional motivation for research to substitute renewable resources for fossil fuels, as they provide independence from fossil fuels, especially for economies which are focused on agriculture. Bio-based industries on the EU level and bioeconomy in Germany represent large funding initiatives [1-3]. Technologies considered in principal are either "white biotechnology" or "renewable resources", and plant-based systems, with "flow charts" existing in abundance [4], pilot scale operations being considerably less [5,6], while only a few have been realized as fully operated plants [4,7].

The range of applications is fairly comprehensive for mobility and ranges from replacement of diesel and gasoline all the way to the generation of energy via biogas, and as raw materials for the chemical and pharmaceutical industry (ChPI) instead of exhausting fossil sources [8-10].

Renewable resources and biotechnology are not by definition more ecological; instead a careful process technological optimization is required in combination with closing the loops (recycles) and establishing economic scenarios in globalized markets including the setup of integrated eco-balances. Otherwise, an unnecessary and fruitless emotional discussion without a sustainable outcome will result. Plants are not good per se, but also require resources for cultivation, harvesting, and processing, for example, corn can sometimes be dangerous and poisonous such as digitalis (Digitalis purpurea L.) and heracleum (Heracleum mantegazzianum Sommier et Levier). Introduction of invasive species into new environments can have a drastic environmental impact. Furthermore, excessive and unsustainable industrial cultivation of renewable resources can damage any ecosystem, e.g., clearing of rainforest for 
palm oil production or soil erosion from energy corn cultivation [11-13]. On the other hand, crude oil is not à priory bad because of its high energy density and efficient processability [14,15].

As always, much depends on how resources are handled, which products result, and what the resulting overall benefit is. For a long time, packaging materials from renewable resources in contrast to synthetic polymers were not biodegradable [16]. Biotechnology today can even compete economically for production of bulk chemicals like ethanol or acetic acid, if the internal cycles are fully optimized and closed [17]. So far, attempts to produce polymers from succinic acid or lactic acid have not been successful, and producing tires with rubber from Taraxacum officinale F. H. Wigg has a niche status so far and may not be further pursued [5].

Using renewable resources in cultivation for energy production, for example, energy corn for biogas plants, generates monocultures due to the area required. The ethical public discussion "container vs plate" or "energy vs plate" enforces in a first stage a complete use (or utilization) of the existing food waste, which is currently not the case, and due to the logistics by no means trivial. One approach may be the setup of "trading houses" for available sources of renewable resources $[18,19]$. Additionally, most specialty crops are cultivated and refined in small regions, resulting in unique waste in high quantities, for example, artichoke, wine, hops, and olives [20-25].

An approach which is more target-oriented for setting up technological support programs is similar to those employed for the development of environmental technology programs during the 1980s. This has benefited the German industry until today, even after solving the environmental issues, for example, acid rain or air quality occurring from 1960 to 1970. A key task and challenge of process technology which remains to be developed is consistent business models including an assessment of economic feasibility linked to sustainable eco-balances.

The introduction of bioeconomy can provide a chance to correct or adjust non-sustainable technological developments in the current economic system, especially in the industrialized agricultural sector. The development of methods for the valorization of waste products is exceptionally useful, for example, animal husbandry or special crops. Use of plants for energy, be it central, decentralized, or mobile, is equally sustainable (or not) as are fossil energies, e.g., coal, crude oil, or gas. Utilization of residuals and waste, or side stream valorization is so far not too widespread, however, it enjoys strong growth worldwide in Europe as well as in Germany [26-32].

The utilization of primary and secondary metabolites as value products is also integrated in this concept, following the basic idea of not breaking down the synthetic performance of the plants first by disintegration into small building blocks and then recombining them by fermentation, but to first extract the value compounds, e.g., amino acids, peptides, and proteins as primary metabolites, and also extract secondary metabolites, e.g., polyphenols or flavonoids [33,34]. This must not affect further processing steps, and therefore the process engineer typically falls back to natural solvents, ideally water $[17,35-40]$.

\section{Actors and Involved Disciplines}

The current approach to bioeconomy is focused on the substitution of conventional products with sustainable alternatives. Often, process and product development are limited to one single component. This greatly reduces the potential for the utilization of side components. The access of these components requires major changes in the traditional production process and thorough knowledge of the composition of the raw material.

The function of process technology is, due to its central position within the value chain, impacted both from the application side at the end and from the materials supply side, as shown in Figure 1. 


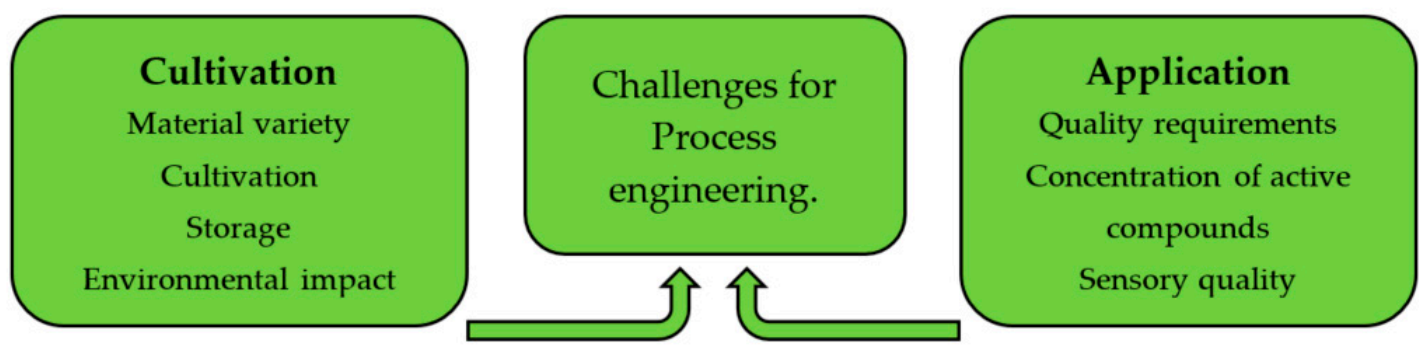

Figure 1. Challenges for process engineering between agriculture and application.

The characterization of material variability and cultivation conditions is a well-established area of interest for conventional industrialized farming, but the focus is still high yield and singular use for food production. An extended focus could also include the potential of valuable compounds, which are currently not utilized. The combination of deep knowledge about the raw material and the reinvention of traditional production processes is a main challenge for bio-economists.

Advanced approaches for the characterization of raw materials are the following current fields of research:

- Metabolic pathways of secondary plant metabolites (OMICS Technologies) [41,42];

- Growth of highly productive plants [43-45];

- Optimization of growth conditions for environmental impact content and yield [46-49].

The role of process technology is to subsequently maintain the quality range of the raw material and to adjust and compensate variations from environmental sources. The techniques to utilize for this purpose strongly depend on the desired product properties. Developing quality profiles of biogenic products is a substantial research area in the following contexts:

- Clarification of the metabolic profiles of secondary plant ingredients [50-52];

- Use of secondary plant ingredients for therapeutic application for animals and humans [53-59];

- Use for defense against undesired plants, bacteria, and fungi $[60,61]$;

- Application for improving material properties.

\section{Technological Processing of Biogenic Raw Materials}

An improved value generation with simultaneously enhanced resource and energy efficiency can be reached by technologically driven processing of the plant material. As examples, the production of sugar from beet, the isolation of starch from potatoes or the extraction of hops are listed in [62,63]. These highly integrated processes allow efficient processing of up to 15,000 t raw material per day, and efficient use of energy by proper integration of waste streams [64]. In addition, the high throughput of raw material allows for efficient use of byproducts which build up during the production process. Current concepts often focus on the generation of energy from biomass, neglecting the potentials of secondary plant ingredients [4].

An extension of this production technology to other processes, e.g., processing of Curcuma longa will allow higher process efficiency as well as access to new products, which cannot be recovered by traditional means.

The traditional processing path that focuses on the production of turmeric is marked in Figure 2 by the blue arrows $[43,65]$. Cooking of the rhizomes prevents recovery of starch, which is present in Curcuma longa. The subsequent drying step, which often takes place in the open in small scale production facilities, is why etheric compounds with interesting properties get lost [66,67]. The final product, Curcuma powder, contains, among others, the compound group of curcuminoids which are a candidate for various medicinal therapies $[68,69]$. This process could be a prime example, where reinvention of the traditional process could make additional products accessible. This phenomenon can be observed in many industries. 


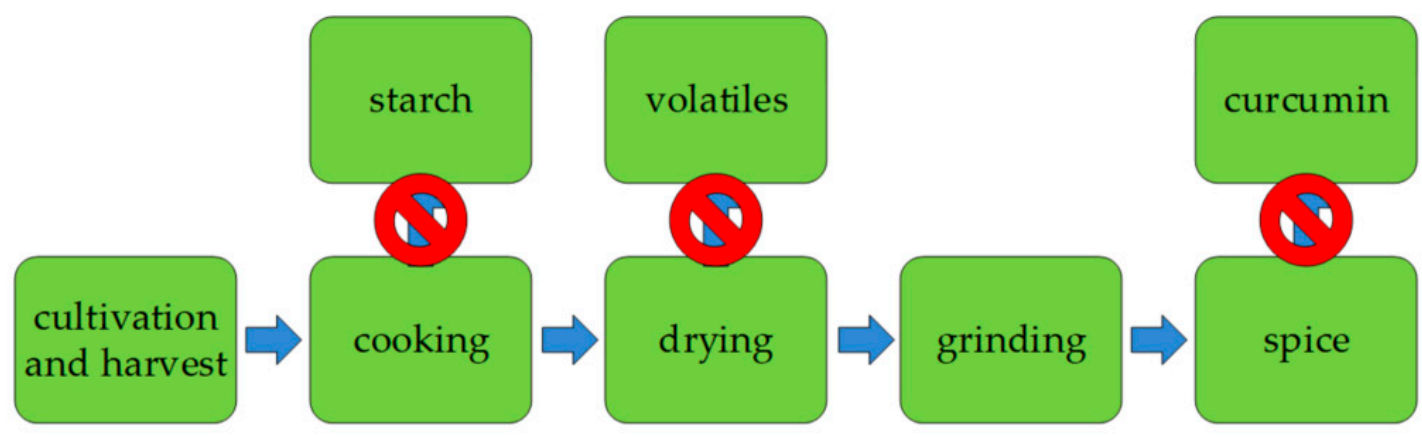

Figure 2. Loss of potential products by the restricted focus on traditional process technology.

Additional to cultivation costs and costs for logistics and marketing, the production costs are important for the economic success of a product. These costs are highly dependent on the source of the resource and the required level of final purification. The comparison of sugar $(0.4 € / \mathrm{kg})$ with the price of commercially available hawthorn extract $(450 € / \mathrm{kg})$ shows the cost efficiency of sugar processing compared to the processing of medicinal plants $[70,71]$.

Different separation techniques that are in use for enhancement processes and have been developed for applications in the pharmaceutical field are:

1. Extraction is the classical separation method for secondary plant ingredients from the plant matrix. Many extracts are used in the medicinal area and defined by monographs [24,27,72-79].

2. Distillation allows the recovery and reuse of the extraction solvent and a separation based on the boiling points of the individual components. The solvent free residues are sold as dried extracts or further purified [80].

3. Liquid-liquid extraction of a liquid extract with a second, non-miscible solvent can be used to further reduce the side-component spectrum of the product. Depending on the operation of the extraction, the product purity can be further enhanced $[40,81]$.

4. Adsorption and chromatographic separation techniques allow the purification of complex mixtures. These techniques, in particular, are applied to the separation of pure compounds [72,82].

5. Crystallization is a separation technique which allows a separation of compounds based on their melting point or solubility $[39,83]$.

In addition, mechanical separation processes (sieving, air separation and electrostatic separators) can be used for selection and classification of raw materials.

These separation techniques have been developed and adopted to produce high value products for a long time. Significant improvements regarding process robustness and costs make them the tool of choice to isolate new products from traditional processes, like the process shown in Figure 2.

\section{Value-Added Products from Sustainable Raw Material}

The potential of secondary plant ingredients as a basis for value generating products is high. Especially well-known are plant ingredients occurring in food and contributing to the positive impact of healthy nutrition $[84,85]$. Especially in agricultural regions and countries the necessary work up of the material is performed by the farmer $[86,87]$. The processing of single harvests often does not allow the utilization or work up of waste streams, as they occur in too small amounts to permit economical extraction.

The potential of secondary plant ingredients is, however, not limited to health promoting effects from eating the plant of a respective compound. Often the positive potential of the respective compound cannot be utilized by the intake of the ingredients alone, because the concentration is often not more than $1 \%$ of the dried raw material, or bioavailability is not sufficient [44,87-89]. In addition, many plants often generate not only one form of a compound, but different forms with varying properties. The low concentration of these compounds in the raw material prevent an economic isolation of the materials in 
the processing range of 50 tons raw material per year, which is the typical range for small and medium enterprises in the extraction.

The comprehensive use of process technology for the use of biogenic raw materials is well established up to a scale of sugar production. These processes allow processing of plant material in the range of several 10,000 tons per day [90,91]. Contrary to primary plant ingredients, as in the case of sugar and starch, secondary plant ingredients are often present in much smaller concentrations in the raw materials, as shown in the following tables. Many concepts for the development of biorefineries focus on primary plant ingredients for production of materials or energy carriers with a selected number of examples are listed in Table 1 [92-95].

Table 1. Industrially produced primary plant ingredients.

\begin{tabular}{cccc}
\hline Plant Material & Content & Quantity & Source \\
\hline Sugar beet & Saccharose & $18 \%$ of fresh mass & {$[70]$} \\
\hline Potato & Amylose, Amylopektin & $15-20 \%$ of fresh mass & {$[96]$} \\
\hline Wood material & Lignin & $20-30 \%$ of fresh mass & {$[97]$} \\
\hline
\end{tabular}

The sources of raw material compete with traditional food supply, which also contains active ingredients [98]. Only further processing allows collection of products in enough concentration for identification of a therapeutic effect. In the case of Curcuma longa, processing turns the starch present into a paste-like consistency during cooking and as such cannot be isolated and utilized, even though starch represents approximately $20 \%$ of the fresh mass of Curcuma longa roots [99].

Currently, traditional herbal medicinal products do not generally need to be provided as pure compounds. Efficacy of many plant-based products is recognized by EMA (European Medicines Agency) and manufacturing of plant-based pharmaceuticals is laid down in monographs [100-102]. However, the regulatory agencies have shown growing interest in the identification of side components and their effect on the product efficacy. High value products listed in Table 2, e.g., 10-DAB III (taxotere $\left.{ }^{\circledR}\right)$, which is used for the treatment of various cancer types or artemisinin and for the therapy of malaria, require high purity. The cost of generating or improving a biogenic product strongly depends on the level of purification [78].

Table 2. Presence of secondary plant metabolites.

\begin{tabular}{ccccc}
\hline Plant Material & Active & Concentration & Product & Source \\
\hline Artemisia annua L. & Artemisinin & $0.4 \% \mathrm{TM}$ & pharmaceutical & {$[103]$} \\
\hline Piper nigrum L. & Piperin & $6.5 \% \mathrm{TM}$ & nutrition & {$[104]$} \\
\hline Taxus baccata L. & 10- DAB III & $0.3-0.7 \%$ TM & pharmaceutical & {$[78]$} \\
\hline Curcuma longa L. & Curcumin & $3-5 \% \mathrm{TM}$ & nutrition & {$[43]$} \\
\hline
\end{tabular}

\subsection{Requirements for the Design of Processing Plants to Recover Secondary Plant Ingredients}

Process development does not stop with the identification of useful components or the design of resource efficient separation processes.

The logistics of the raw material is an important element of the value chain. The use of biogenic resources has specific requirements for the technical implementation in manufacturing plants. Already, many value products containing plants degrade shortly after harvest and have to be immediately either dried or processed. The example of sugar processing shows that the raw material is spread over large areas, as seen in Figure 3. [105]. Modern plants for sugar refining are designed to handle more than 10,000 tons per day.

However, for the secondary plant ingredients in pharmaceutical or cosmetic applications amounts of less than 100 tons of raw material per year need to be processed, and therefore require only small 
plants, which allow for provision of a high level of added value. The feasibility of implementing such a decentralized infrastructure is demonstrated by the development and deployment of Biogas plants in Germany from 2007 to 2015, which is shown in Figure 4. During this time, approximately 8000 plants were installed in order to produce biogas from biomass [106].

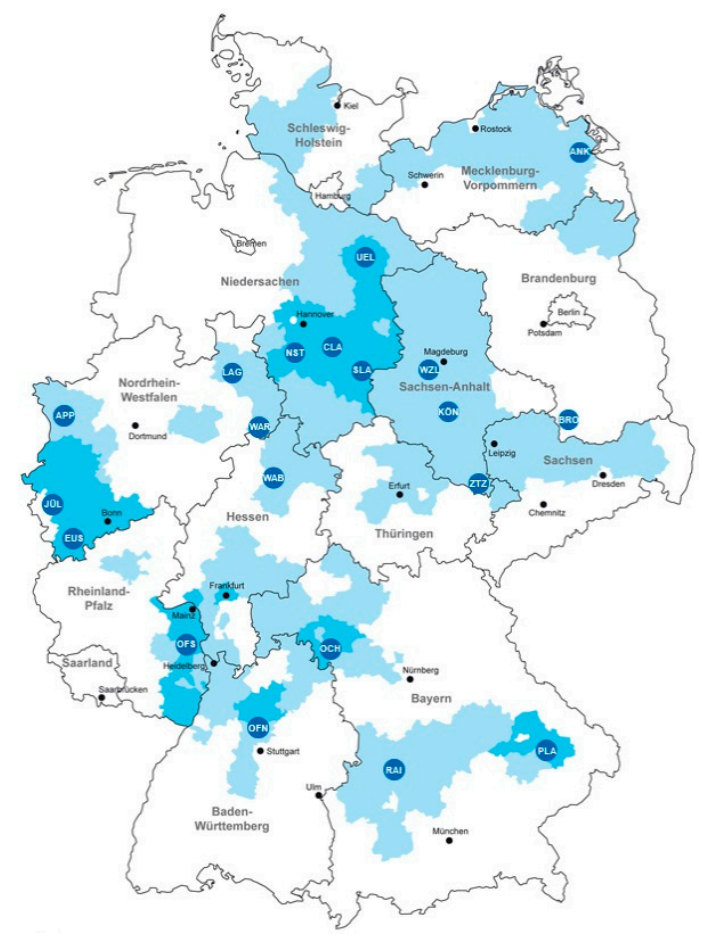

Figure 3. Cultivation area of sugar beet and location of processing plants [107].

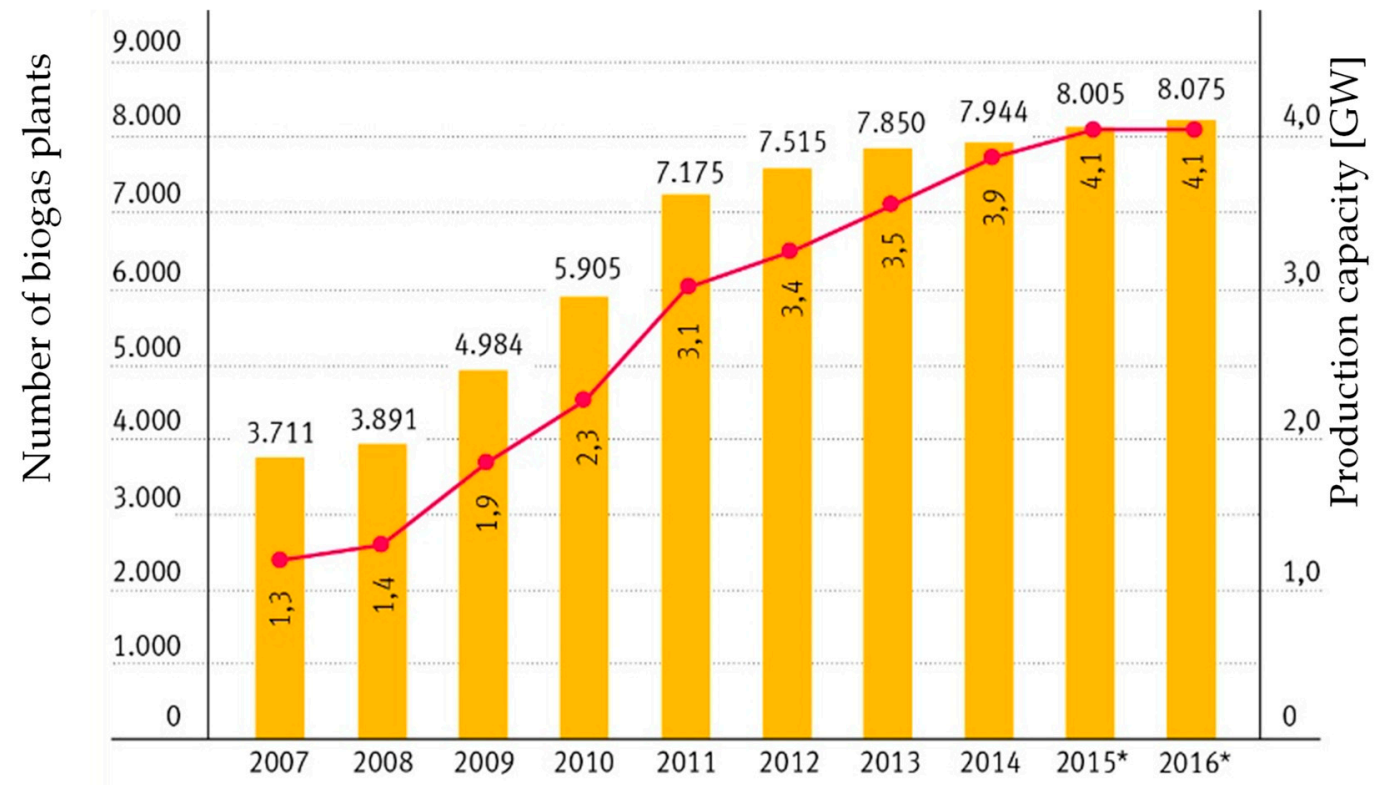

Figure 4. Number of plants (left axis) and corresponding production capacity in Gigawatts (GW) (right axis) of biogas plants in Germany, from 2007 to 2016 [108].

\subsection{Economic Assessment of Biogas Generation}

The generation of biogas is an interesting field from an engineering point of view. The utilization of decentralized, small-scale production plants could be one solution to the logistical challenges described 
above. Unfortunately, biogas generation is under increasing economic pressure due to declining funding/subsidies and declining energy prices. This pressure becomes especially evident when comparing price development for electricity over the last years. As can be seen in Figure 5, the price between 2011 and 2018 fell 35\% to $3.48 \mathrm{ct} / \mathrm{kWh}$. The comparable call for electricity from biomass plants required to be run renewable energies since 2017 has a median price of $14.20 \mathrm{ct} / \mathrm{kWh}[109,110]$.

The same call for electricity from wind farms in February 2018 has resulted in an average current price of $4.73 \mathrm{ct} / \mathrm{kWh}$. This is significantly below the market price for power from biogas. With the high compensations on old supply contracts from biogas plants running out, it is questionable, whether all existing biogas plants can still operate profitably in the future [108]. Biogas plants, which rely to a high degree on energy crops as feedstock, see the highest economic pressure.

The use of biomass with the primary goal of electricity production must be reconsidered. The German biomass research center (DBFZ) expects a decline in biogas plants to continue until 2030 [111].

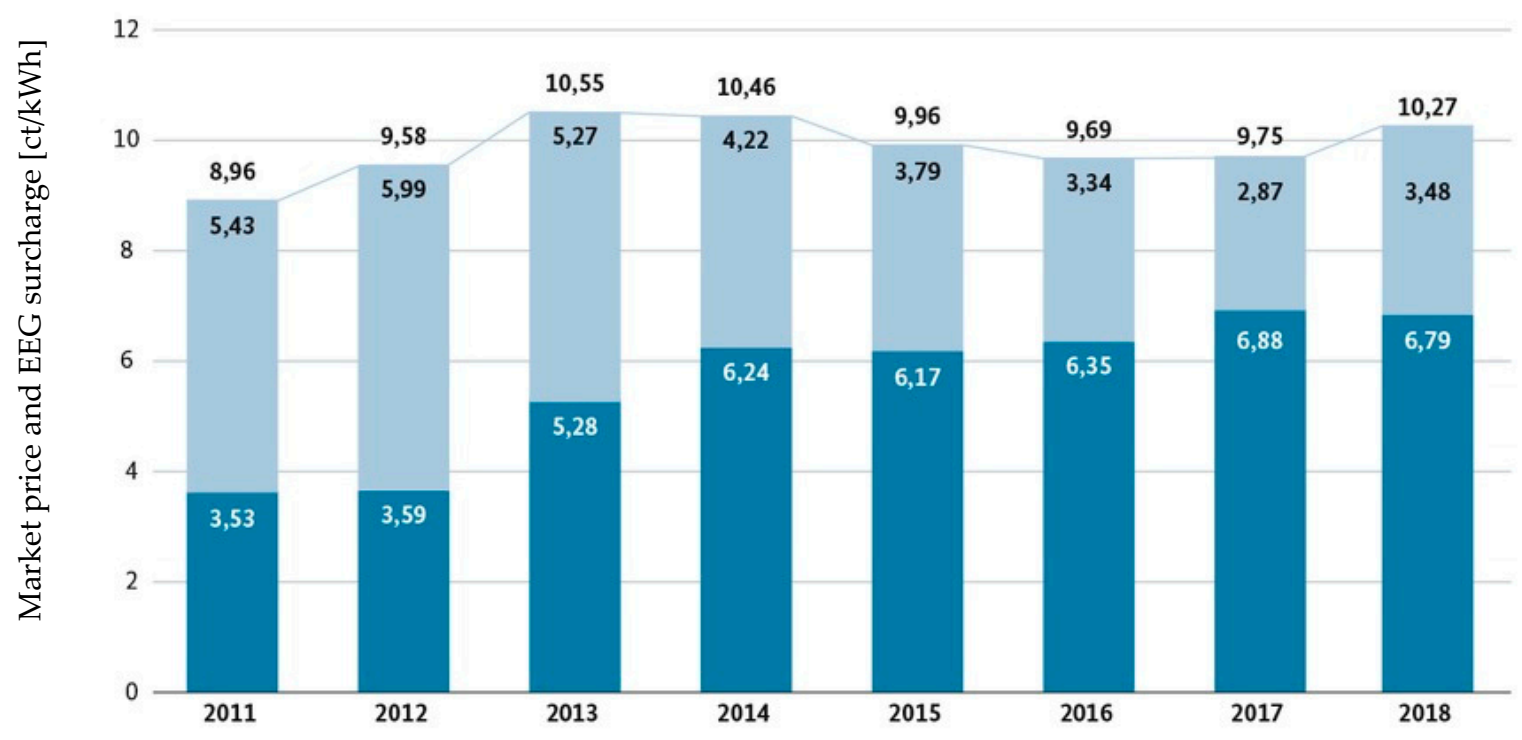

Figure 5. Sum of market price for electricity and EEG surcharge 2011-2018 [112].

A network of decentralized processing plants for production of secondary plant ingredients, comparable to biogas plants provides access to additional products, enabling a better utilization of the plant-based raw material. Subsequently, the extracted plant residues can still be transferred into energy.

\subsection{Production of Necessary Raw Materials}

Examples of renewable resources used by industry are sugar, plant-based oils, and starch. They are cultivated in Germany on a total area of 270,000 acres, equivalent to a share of $2.4 \%$ of the total available agricultural area (Figure 6, left side) [113]. This is in comparison to an area of 2.39 million hectares for the generation of biomass, which is primarily used for energy purposes (Figure 6, right side). Approximately 1.34 million ha, $11.37 \%$ of the German agricultural area, are allocated to grow energy plants for biogas production according to data from FNR and BMEL [114]. 

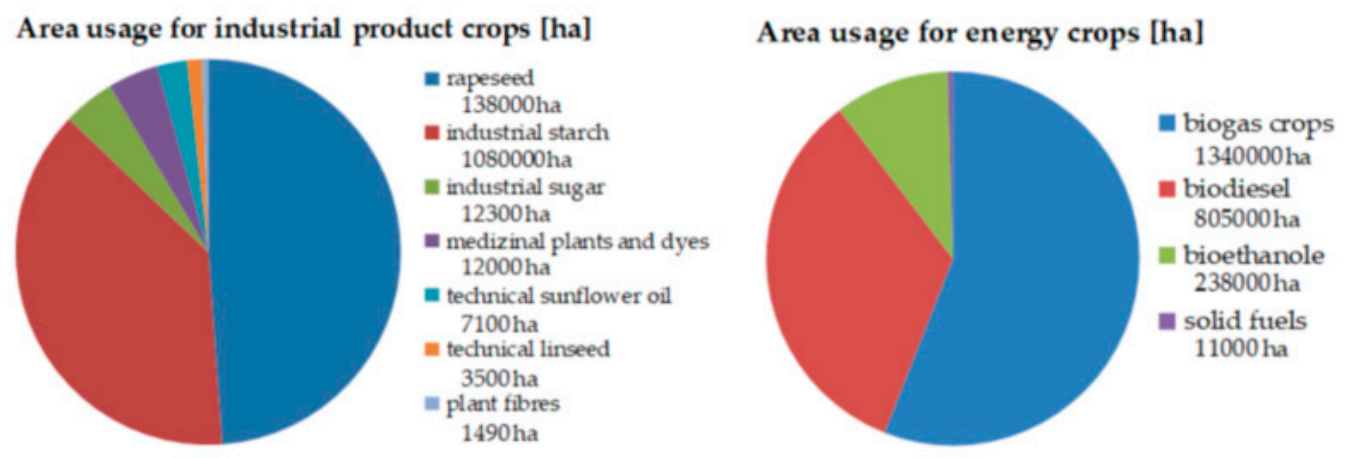

Figure 6. Area usage for industrial and energy crops in Germany in hectares [114].

The economic pressure on biogas production can reduce demand for these crops, which has the opportunity to establish new cultivations with additional uses. In the value chain for the energetic use of biomass, no utilization of the secondary metabolites of feedstock is considered. However, a successful implementation of a bio-economic model depends on an optimal utilization of efficient plant ingredients, if they want to provide an alternative to established products.

Therefore, the growth and direct use of energy plants not only directly competes with food production, but, in addition, leaves a large potential for secondary plant ingredients to be unused. In addition, growing biomass for the isolation of secondary plant ingredients, such as curcumin or others, allows for further energetic use of the biomass, which is a common practice in sugar production [107]. It must be kept in mind, that the biomass yield of plants, producing valuable secondary metabolites, is typically lower than that of optimized energy plants. The impact on the electricity generating community in Germany, however, is minimal due to the small share of biomass based in energy generation [115]. Nevertheless, the energetic use of biomass through biogas generation remains to be a useful technical application of renewable energy [116].

The generation of biomass is labor- and cost-intensive, resulting in high prices. The contribution margin, for example potatoes in Germany, is in the range of $2000-2500 € /$ ha, with potato production being a well-established process using specialized equipment and optimized procedures $[117,118]$. Other field crops such as sugar beet, corn, and alternative substrates for biogas generation are calculated with contribution margins in the range of 1000-1200 $€ /$ ha [119-121]. Depending on the condition of the plant material during processing, the processing costs, as well as the logistics between the field and the processing plant, need to be added to the contribution margin. These additional costs can be significantly higher than the contribution margins. As an example, the full cost for the cultivation of potatoes is calculated as $4600 € /$ ha, which is approximately twice the contribution margin [118].

As cost calculation is correlated to the area in use, for the estimation of raw material costs of a biomass processing plant with the goal of producing secondary plant ingredients, the revenue per area for the raw material processed must be assessed. A selection of yields for field crop is shown in the following Table 3.

Table 3. Agricultural yield for selected field crop.

\begin{tabular}{cccc}
\hline Plant Material & Fresh Mass Yield & Utilized Yield & Source \\
\hline Sugar beet & $76 \mathrm{t} / \mathrm{ha}$ & n.a. & {$[122]$} \\
\hline potato w/o greens & $45 \mathrm{t} / \mathrm{ha}$ & n.a. & {$[122]$} \\
\hline St. John's wort & $20 \mathrm{t} / \mathrm{ha}$ & $7.5 \mathrm{t} / \mathrm{ha}$ & {$[45]$} \\
\hline Wheat plant & $26 \mathrm{t} / \mathrm{ha}$ & n.a. & {$[122]$} \\
with grain & n.a & $7.6 \mathrm{t} / \mathrm{ha}$. & {$[122]$} \\
\hline Stinging nettle & $26.4 \mathrm{t} / \mathrm{ha}$ & $2.7 \mathrm{t} / \mathrm{ha}$ & {$[45]$} \\
\hline Curcuma without greens & $17-60 \mathrm{t} / \mathrm{ha}$ & n.a. & {$[43]$} \\
\hline
\end{tabular}




\subsection{Economic Potential of Process Technologically Enhanced Products on the Example Processing of Curcuma longa}

Curcuma longa belongs to the family of Zingiberaceae, and in particular, in Asian countries, it is grown as a spice plant [74]. The rhizomes of Curcuma longa contain 3-5\% curcuminoids as well as $2-7 \%$ etheric oils and starch [123].

Curcuminoids possess a variety of properties, which have been investigated and are of interest for medicinal applications [75,124-126]. Traditionally, the rhizomes of the Curcuma longa are cooked, dried, and ground after harvest by the farmers [127].

If the cultivation of Curcuma longa is comparable to the cultivation of potatoes, similar full costs in the range of $5000 € / \mathrm{ha}$, as cited above, can be assumed. Together with an estimated yield of $50 \mathrm{t} / \mathrm{ha}$, as reported in the literature cited in Table 3, the cost of the raw material is approximately $100 € / \mathrm{t}$.

The following three scenarios serve as a starting point for the evaluation of the process concepts:

1. Traditional two people farm, plant capacity $0.2 \mathrm{t} / \mathrm{d}$, low overall efficiency (wood-based energy generation, no energy recovery);

2. 100 worker production facility with $25 \mathrm{t} / \mathrm{d}$ capacity, average efficiency (oil-based energy supply, simple energy recovery);

3. Large-scale processing such as sugar plant (integrated power plant, efficient energy recovery and utilization).

The process concepts are based on published studies in laboratory scale as well as reports on generation and processing of Curcuma longa. Investment costs are assessed in a class 5 cost approximation, based on the processing scheme and the costs of known plants [128,129].

The concepts are summarized in Table 4, showing the production capacity and catchment area of each scenario, together with the different assumptions regarding fuel source and efficiency.

Table 4. Key parameters of the assessed production scenarios.

\begin{tabular}{cccc}
\hline Key Parameters & Scenario 1 & Scenario 2 & Scenario 3 \\
\hline Processing capacity/a & 25 t/a & 3200 t/a & $1,782,000$ t/a \\
\hline Catchment area & 0.5 ha & 64 ha & 35,640 ha \\
\hline Energy efficiency & $10 \%$ & $30 \%$ & $80 \%$ \\
\hline Fuel & wood & diesel & coal \\
\hline Product/manufacturer & 0.01 t/a & 22 t/a & 13,000 t/a \\
\hline Employees & 2 & 80 & 130 \\
\hline Products & curcuminoids & curcuminoids & curcuminoids starch essential oil \\
\hline
\end{tabular}

The classic processing of Curcuma longa markets curcuma spice as a product. The traditional processing is done by the farmers who grow and harvest the plants, as well as process the harvest and sell the final product.

This decentralized production described in scenario one uses all available resources, i.e., wood for heating the kettles. Therefore, resource efficiencies for these processes are quite low, while the corresponding manual labor is quite high. Scenario two can be visualized as a farmer collective, utilizing mechanized cultivation and harvesting to improve energy efficiency and productivity. Current approaches to access the curcuminoids use the curcuma spice as the raw material for isolating the pure compound. Therefore, the production of curcuma spice is included in the economic considerations.

The process consists of the steps which are shown in Figure 7. In the first step the fresh raw material is cooked, whereby, the starch in the root agglomerates and this improves the milling properties [43]. Then the material is dried. The dry material is extracted with ethanol. From the extract the curcumin can be crystallized. 


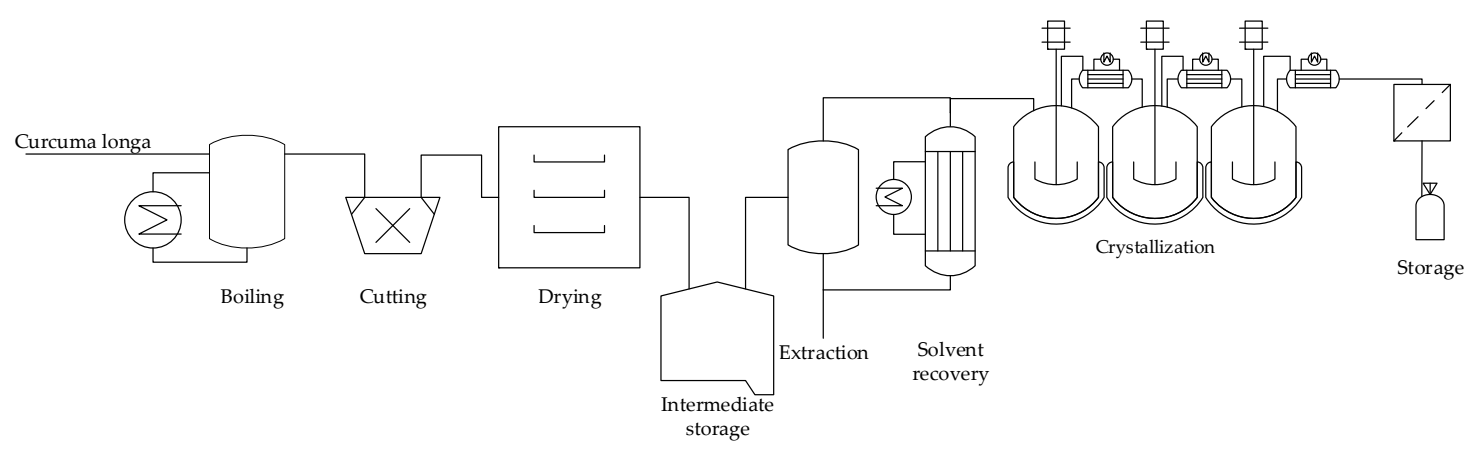

Figure 7. Small and medium scale extraction process for purification of curcumin.

The alternative, large-scale approach considered in scenario three allows collection of the starch fraction and the etheric components of Curcuma longa, in addition to the main product curcumin, during processing. These product fractions are lost during the cooking and drying of the traditional processes, as described in scenario one and two.

Figure 8 represents the schematics of the large-scale production process which was derived from the sugar processing process.

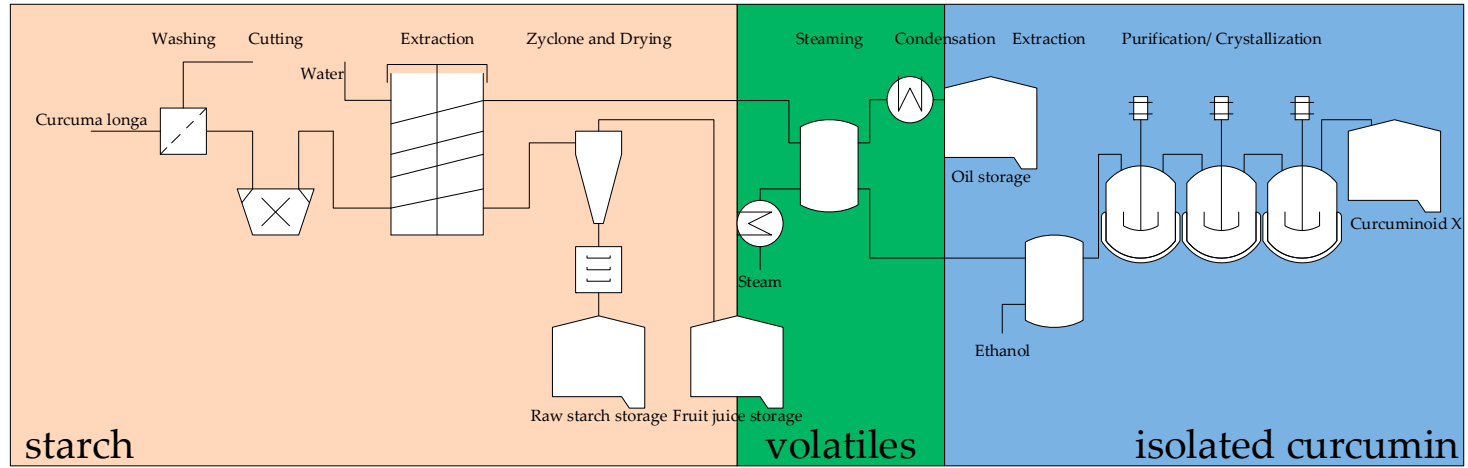

Figure 8. Large-scale process for the extraction of starch, etheric components, and curcumin.

Looking at the cost of the process in Figure 9 it can be concluded that overall costs decrease with increasing scale of the process, which is the typical effect of economy of scale. This cost decrease stems from an improved energy efficiency, higher plant utilization, and lower specific investment costs, and it is reflected in a decrease of the specific production cost by a factor of five, which is shown on the left side of Figure 9. Better utilization of the raw material allows for the redistribution of production cost to additional products, such as starch and the volatile fractions, whereby, the production cost of curcumin can be reduced by a factor of three. On the right side of Figure 9, the distribution of the production cost in scenario three within the process is shown.

The annual costs of operation are shown in Figure 10. The major share of the operating costs, which is around $70 \%$, is associated with the acquisition of the raw material. This distribution is typical for the processing of renewable resources, highlighting the importance of cost-efficient production processes. Other major contributions to the total operating costs are extraction and solvent-recovery. The extraction costs are driven by replacement, which is assumed to be $10 \%$ of solvent volume per year. Solvent recovery is cost intensive because it requires large amounts of energy for vaporization and condensation. 


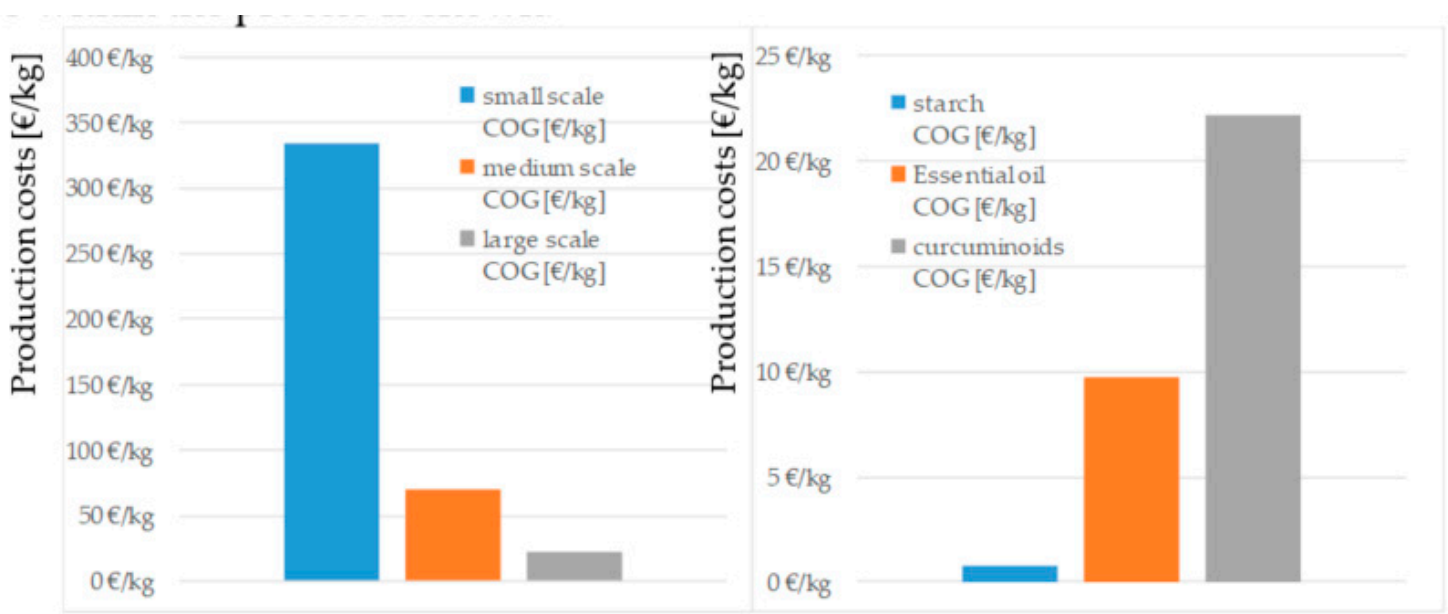

Figure 9. Comparison of production costs for the different scales (left) and distribution of production cost by product of scenario three (right).

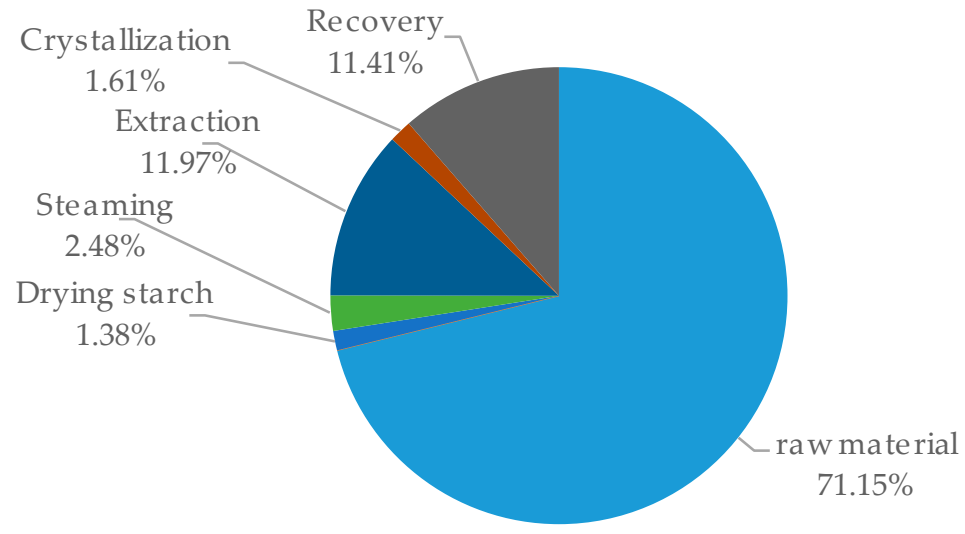

Figure 10. Distribution of operating costs.

Assuming a share of $70 \%$ for distribution, logistics, and taxes, as well as a desired return on investment (ROI) of 3 years, the following prices for the three considered scenarios are found to be:

- Scenario 1 price of curcumin is $1475 € / \mathrm{kg}$;

- Scenario 2 price of curcumin is $310 € / \mathrm{kg}$;

- Scenario 3 price of curcumin is $187 € / \mathrm{kg}$, essential oil is $30 € / \mathrm{kg}$ starch is $1 € / \mathrm{kg}$.

The most obvious conclusion from these considerations can be reached by comparing these prices with of the products displayed in Figure 11. This comparison shows that cost-efficient production of secondary plant metabolites is possible in every scale, for medium to high-end products, i.e., aroma or pharma applications.

Especially, processes that have a high throughput for the low-price segment, for example sugar and starch, could profit from additional products which would compensate for the high raw material costs and increased resource utilization. The isolation of secondary metabolites with an average content of $0.1 \%$ and with $50 \%$ yield from the raw material of a typical sugar production plant, cf. Table 4, would amount to 890 tons of product per year. On the other hand, medium scale production, which focuses on the isolation of high value products, as seen in scenario two, could produce an additional amount of 160 tons of primary metabolites, with an average content of $10 \%$ and $50 \%$ yield.

It must be kept in mind, in order to use specific curcuminoids for a pharmaceutical preparation further costs arise for final purification and formulation. The additional efforts and the subsequent significantly increased production costs are offset by the higher value of the final product. 


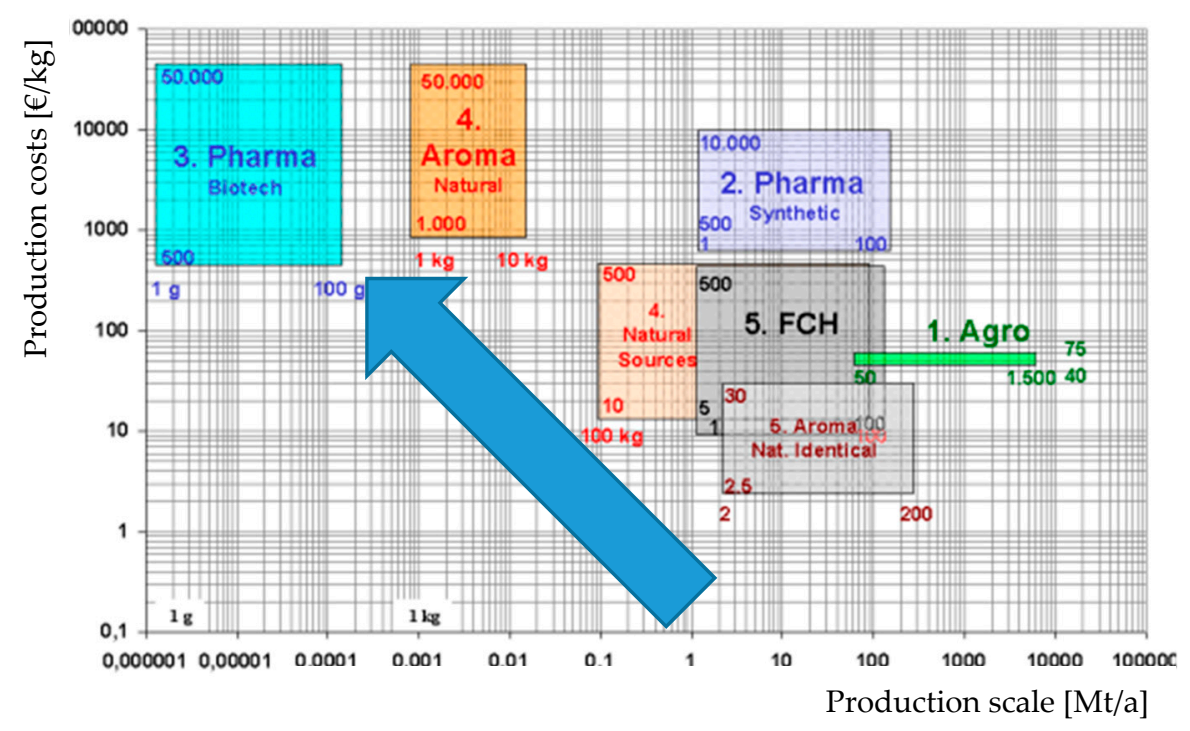

Figure 11. Dependency of production costs on the target market [130].

\section{Summary and Conclusions}

Decentralized and small-scale production solutions for agricultural communities is a way to produce new and renewable products. The purification of isolated structures from plants will be of increasing importance in the future. Innovative technologies create optimal COGs [35], especially, process intensification such as hybrid separation technologies or integration of reaction and separation, for example phyto-SMB (simulated moving bed) chromatography processes may be a solution.

Counter-current processing, as depicted in Figure 12 efficiently utilizes most resources such as adsorbent and solvent amount, and in addition, integrating separation and reaction is a well-known tool for process intensification [131-137].

The value chains of plant-based products can be extended by the extraction of secondary plant metabolites which requires efficient separation techniques.

Current concepts for use, such as the energetic use of biomass, must be reconsidered, because the potential of primary and secondary contents are not utilized/exploited. The high cost of farming and the limited available farming area makes a more intensive use of the available raw materials that are indispensable for the progress of a bio-based economy. Nevertheless, the generation of energy from biomass is still a viable option for the valorization of waste streams from industrialized farming, e.g., manure from animal husbandry. The current usage of energy crops should be reconsidered. In light of the overproduction of crops for food production, alternative crops and economic products are needed to provide an incentive for the cultivation of currently uncommon crops. An increase in scientific work is needed to provide new materials and technological solutions for the manufacturing of such products.

First, examples for new products and alternative feedstocks are already available, but require additional optimization to become competitive, while maintaining sustainability. One approach is the substitution of conventional solvents with solvents made from biomass, e.g., Pinen, 2-Methl THF, vegetable oils and others. Additionally, new packaging materials could provide a more sustainable alternative to conventional polymers and provide use for currently unused waste stream. This approach has been expanded to bulk chemicals, e.g., alternatives to rubber from dandelions. Examples of new products from renewable resources are food additives, such as amino acids, peptides and proteins. The development of new techniques for the refinement of natural raw materials could also provide new value products, for example flavonoids, polyphenols and aroma. 

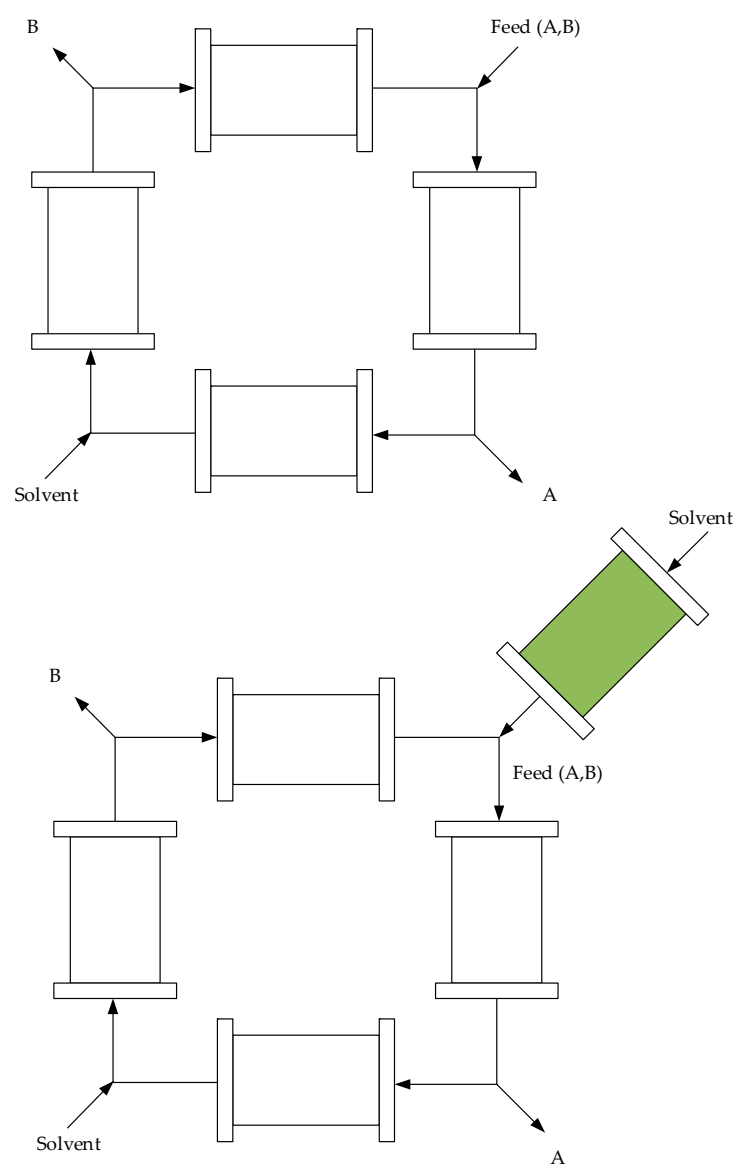
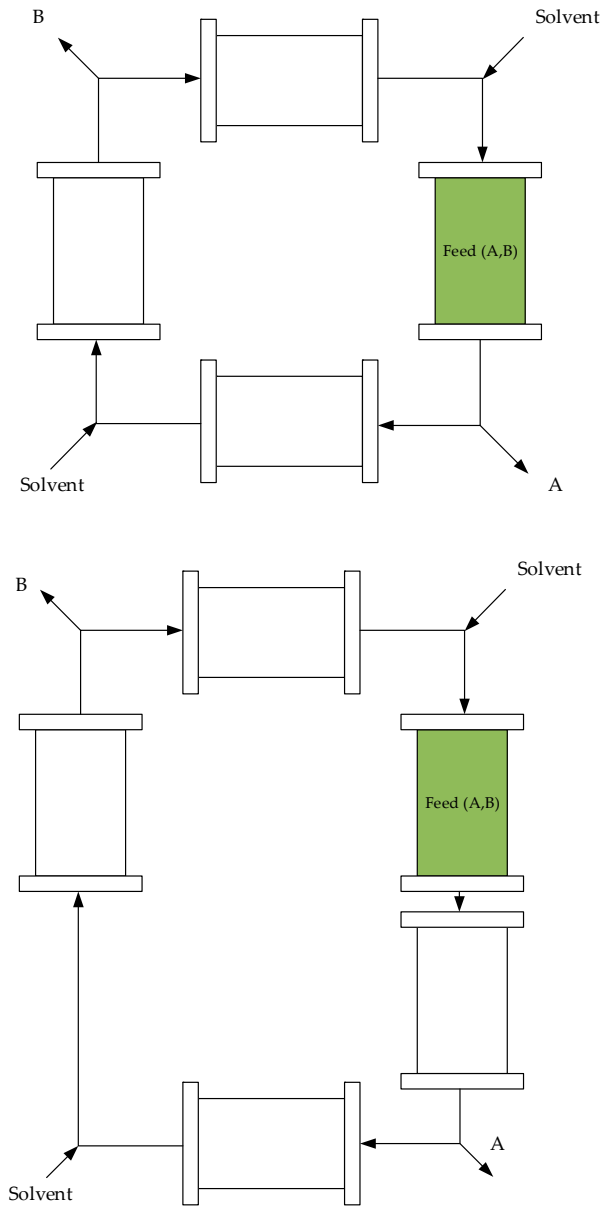

Figure 12. Potential configurations of Phyto-SMBC, upper left: conventional SMBC, all other flow charts depict potential process options of Phyto-SMBC processes, plant raw material in green with component faction A strong binding in chromatography as extract and component faction B as weaker binding raffinate.

The example of the generation of curcumin from Curcuma longa demonstrates the limitation of resources used by traditional production technology with a focus on single products and the potential of the expansion of existing production processes. At the same time, the development of large-scale processes, as shown in scenario three for the example of a plant size, the scale of a sugar plant, is not reasonable without limits, as very large areas are required for supplying the raw materials. The efficiency which is increases by the improved process technological handling suffers from the strong increase of the necessary logistics, and therefore it loses its economic impact.

The concept of large-scale biorefineries cannot simply rely on economy of scale, because of the area requirements of agricultural crops. A possible alternative as a compromise between processing efficiency and logistics is the development of efficient processing plants with capacities in the range of 5000 tons per year, which could be supplied by local agricultural associations.

Author Contributions: Conceptualization, L.U. and J.S.; writing—original draft preparation, L.U.; writing一review and editing, L.U., R.D. and J.S.; visualization, L.U.; supervision and project administration, J.S.

Funding: This research received no external funding.

Acknowledgments: The assistance of Alex Juckers and Gesa Weber for research work regarding the processing of curcuma longa is gratefully acknowledged.

Conflicts of Interest: The authors declare no conflict of interest. 


\section{References}

1. Office of Energy Efficiency and Renewable Energy. Available online: https://www.energy.gov/eere/officeenergy-efficiency-renewable-energy (accessed on 12 May 2019).

2. Natural Resources Canada. Available online: https://www.nrcan.gc.ca/forests/industry/bioproducts/13315 (accessed on 3 December 2018).

3. Bio-based Industries Joint Undertaking. Available online: https://www.bbi-europe.eu/media/bioeconomystarts-here (accessed on 3 December 2018).

4. DECHEMA. Fortschrittliche Alternative Flüssig Brenn-und Kraftstoffe: Für Klimaschutz im globalen Rohstoffwandel. Available online: https://dechema.de/dechema_media/Downloads/Positionspapiere/2017+Positionspapier+ Alt+Kraftstoffe-p-20002790.pdf (accessed on 12 May 2019).

5. Continental Reifen Deutschland GmbH. Kautschuk aus Löwenzahn - Continental entwickelt Nachhaltigkeit. Available online: https://www.continental-reifen.de/autoreifen/media-services/newsroom/taraxagum (accessed on 3 December 2018).

6. Fraunhofer-Institut für Mikrostruktur von Werkstoffen und Systemen IMWS. Available online: https: //www.imws.fraunhofer.de/de/institut/netzwerke/leitprojekte/spitzencluster-bioeconomy.html (accessed on 3 December 2018).

7. Clariant. Cellulosic Ethanol from Agricultural Residues. Available online: https://www.clariant.com/de/BusinessUnits/New-Businesses/Biotech-and-Biobased-Chemicals/Sunliquid (accessed on 12 May 2019).

8. Giovannini, P.; Howes, M.-J.R.; Edwards, S.E. Medicinal plants used in the traditional management of diabetes and its sequelae in Central America: A review. J. Ethnopharmacol. 2016, 184, 58-71. [CrossRef] [PubMed]

9. Pferschy-Wenzig, E.-M.; Bauer, R. The relevance of pharmacognosy in pharmacological research on herbal medicinal products. Epilepsy Behav. 2015, 52, 344-362. [CrossRef] [PubMed]

10. International Energy Agency. World Energy Outlook-German Summary 2017. Available online: https://www.iea.org/publications/freepublications/publication/WEO_2017_Executive_Summary_ German_version.pdf (accessed on 12 May 2019).

11. Developing an Asia-Pacific Strategy for Forest Invasive Species: The Coconut Beetle Problem-bridging Agriculture and Forestry. Available online: http://www.fao.org/3/a-ag117e.pdf (accessed on 12 May 2019).

12. Paini, D.R.; Sheppard, A.W.; Cook, D.C.; de Barro, P.J.; Worner, S.P.; Thomas, M.B. Global threat to agriculture from invasive species. Proc. Natl. Acad. Sci. USA 2016, 113, 7575-7579. [CrossRef] [PubMed]

13. Vogel, E.; Deumlich, D.; Kaupenjohann, M. Bioenergy maize and soil erosion — Risk assessment and erosion control concepts. Geoderma 2016, 261, 80-92. [CrossRef]

14. U.S. Department of Agriculture (USDA). Giant Hogweed: National Invasive Species Information Center. Available online: https://www.invasivespeciesinfo.gov/profile/giant-hogweed (accessed on 19 December 2018).

15. Janssen, R.M.; Berg, M.; Ovakim, D.H. Two cases of cardiac glycoside poisoning from accidental foxglove ingestion. CMAJ 2016, 188, 747-750. [CrossRef]

16. Fraunhofer-Projektgruppe für Wertstoffkreisläufe und Ressourcenstrategie (IWKS). Positionspapier zu Bioplastik. 2018. Available online: https://www.iwks.fraunhofer.de/de/presse-und-medien/pressemeldungen2018/positionspapier-zu-bioplastik.html (accessed on 3 December 2018).

17. Grote, F.; Ditz, R.; Strube, J. Downstream of downstream processing-Integrated bioprocess development from upstream to downstream. Chemie Ingenieur Technik 2009, 81, 1276-1277. [CrossRef]

18. Gustavsson, J.; Cederberg, C.; Sonesson, U. Global food losses and food waste. Extent, causes and prevention; study conducted for the International Congress Save Food! Available online: http://www.fao.org/3/a-i2697e. pdf (accessed on 12 May 2019).

19. Parfitt, J.; Barthel, M.; Macnaughton, S. Food waste within food supply chains: quantification and potential for change to 2050. Philos. Trans. R. Soc. Lond. B. Biol. Sci. 2010, 365, 3065-3081. [CrossRef]

20. Yara-Varón, E.; Selka, A.; Fabiano-Tixier, A.S.; Balcells, M.; Canela-Garayoa, R.; Bily, A.; Touaibia, M.; Chemat, F. Solvent from forestry biomass. Pinane a stable terpene derived from pine tree byproducts to substitute n-hexane for the extraction of bioactive compounds. Green Chem. 2016, 18, 6596-6608. [CrossRef]

21. Chémat, F.; Strube, J. (Eds.) Green Extraction of Natural Products. Theory and Practice; Wiley VCH: Weinheim, Germany, 2015. 
22. Chémat, F.; Vorobiev, E.; Lebovka, N.I. Enhancing Extraction Processes in the Food Industry; CRC Press: Boca Raton, FL, USA, 2012.

23. Chémat, F.; Abert Vian, M. Éco-extraction du Végétal. Procédés Innovants et Solvants Alternatifs; L'Usine nouvelle: Paris, France, 2011.

24. Chemat, F.; Vian, M.A. (Eds.) Alternative Solvents for Natural Products Extraction; Springer: Berlin/Heidelberg, Germany, 2014.

25. Zuorro, A.; Maffei, G.; Lavecchia, R. Reuse potential of artichoke (Cynara scolimus L.) waste for the recovery of phenolic compounds and bioenergy. J. Clean. Prod. 2016, 111, 279-284. [CrossRef]

26. Angela Cardinali. Phytochemicals from Artichoke by-product and Their Applications as Natural Ingredients for Cosmetic Industry. Available online: https://www.uniba.it/ateneo/editoria-stampa-e-media/lineaeditoriale/fuori-collana/genppdf (accessed on 12 May 2019).

27. Fidalgo, A.; Ciriminna, R.; Carnaroglio, D.; Tamburino, A.; Cravotto, G.; Grillo, G.; Ilharco, L.M.; Pagliaro, M. Eco-Friendly Extraction of Pectin and Essential Oils from Orange and Lemon Peels. ACS Sustain. Chem. Eng. 2016, 4, 2243-2251. [CrossRef]

28. Scully, D.S.; Jaiswal, A.K.; Abu-Ghannam, N. An Investigation into Spent Coffee Waste as a Renewable Source of Bioactive Compounds and Industrially Important Sugars. Bioengineering 2016, 3, 33. [CrossRef] [PubMed]

29. Jahresbericht 2018. Johann Heinrich von Thünen-Institut. Available online: https://www.thuenen.de/media/ publikationen/jahresbericht/Jahresbericht_2018.pdf (accessed on 12 May 2019).

30. Di Donato, P.; Taurisano, V.; Tommonaro, G.; Pasquale, V.; Jiménez, J.M.S.; de Pascual-Teresa, S.; Poli, A.; Nicolaus, B. Biological Properties of Polyphenols Extracts from Agro Industry's Wastes. Waste Biomass Valor 2018, 9, 1567-1578. [CrossRef]

31. Watson, R.R. (Ed.) Polyphenols in Plants. Isolation, Purification and Extract Preparation, 2nd ed.; Academic Press: London, UK, 2019.

32. Mourtzinos, I.; Goula, A. Polyphenols in Agricultural Byproducts and Food Waste. In Polyphenols in Plants: Isolation, Purification and Extract Preparation, 2nd ed.; Watson, R.R., Ed.; Academic Press: London, UK, 2019; pp. 23-44.

33. Slivac, I.; Logarusic, M.; Bojanic, K.; Srcek, V.G.; Radosevic, K. Protein hydrolysates from hempseed oil-cake as cell culture media supplement. J. Biotechnol. 2018, 280, S30. [CrossRef]

34. Nastić, N.; Švarc-Gajić, J.; Delerue-Matos, C.; Barroso, M.F.; Soares, C.; Moreira, M.M.; Morais, S.; Mašković, P.; Gaurina Srček, V.; Slivac, I.; et al. Subcritical water extraction as an environmentally-friendly technique to recover bioactive compounds from traditional Serbian medicinal plants. Ind. Crop. Prod. 2018, 111, 579-589. [CrossRef]

35. Uhlenbrock, L.; Sixt, M.; Tegtmeier, M.; Schulz, H.; Hagels, H.; Ditz, R.; Strube, J. Natural Products Extraction of the Future-Sustainable Manufacturing Solutions for Societal Needs. Processes 2018, 6, 177. [CrossRef]

36. Sixt, M.; Strube, J. Systematic and Model-Assisted Evaluation of Solvent Based- or Pressurized Hot Water Extraction for the Extraction of Artemisinin from Artemisia annua L. Processes 2017, 5, 86. [CrossRef]

37. Sixt, M.; Strube, J. Pressurized hot water extraction of 10-deacetylbaccatin III from yew for industrial application. Resour.-Effic. Technol. 2017, 3, 177-186. [CrossRef]

38. Sixt, M.; Schmidt, A.; Mestmäcker, F.; Huter, M.; Uhlenbrock, L.; Strube, J. Systematic and Model-Assisted Process Design for the Extraction and Purification of Artemisinin from Artemisia annua L.-Part I: Conceptual Process Design and Cost Estimation. Processes 2018, 6, 161. [CrossRef]

39. Huter, M.; Schmidt, A.; Mestmäcker, F.; Sixt, M.; Strube, J. Systematic and Model-Assisted Process Design for the Extraction and Purification of Artemisinin from Artemisia annua L.-Part IV: Crystallization. Processes 2018, 6, 181. [CrossRef]

40. Schmidt, A.; Sixt, M.; Huter, M.; Mestmäcker, F.; Strube, J. Systematic and Model-Assisted Process Design for the Extraction and Purification of Artemisinin from Artemisia annua L.-Part II: Model-Based Design of Agitated and Packed Columns for Multistage Extraction and Scrubbing. Processes 2018, 6, 179. [CrossRef]

41. Happyana, N.; Kayser, O. Monitoring Metabolite Profiles of Cannabis sativa L. Trichomes during Flowering Period Using 1H NMR-Based Metabolomics and Real-Time PCR. Planta Med. 2016, 82, 1217-1223. [CrossRef]

42. Ma, X.; Gang, D.R. Metabolic profiling of turmeric (Curcuma longa L.) plants derived from in vitro micropropagation and conventional greenhouse cultivation. J. Agric. Food Chem. 2006, 54, 9573-9583. [CrossRef] 
43. Food and Agriculture Organization (FAO). Tumeric Post Harves Compendium. Available online: http: //www.fao.org/fileadmin/user_upload/inpho/docs/Post_Harvest_Compendium_-_Turmeric.pdf (accessed on 12 May 2019).

44. Bhanu, Y.P. Studies on the Effect of Rhizome Size and Protrays Raised Rhizome Sprouts 2015. Available online: http://krishikosh.egranth.ac.in/handle/1/69959 (accessed on 12 May 2019).

45. Röhricht, C.; Köhler, A.; Brix, B.; Groß-Ophoff, A. Anbautechnische Optimierung des Ertrages und Wirkstoffgehaltes von ausgewählten Heil- und Gewürzpflanzen. Schriftenreihe des Landesamtes für Umwelt, Landwirtschaft und Geologie 2008. [CrossRef]

46. Krishnamoorthy, C.; Soorianathasundaram, K.; Mekala, S. Effect of Fertigation on Fue Quality and Economics. Available online: https://s3.amazonaws.com/academia.edu.documents/37169410/9._Agri_ Sci_-_IJASR_-EFFECT_OF_FERTIGATION_ON_FUE_-_C.Krishnamoorthy.pdf?AWSAccessKeyId= AKIAIWOWYYGZ2Y53UL3A\&Expires=1557656335\&Signature=0DVIVj6Ss5HdZAd5zrnX\%2FZ4ehIA\% 3D\&response-content-disposition=inline \%3B\%20filename\%3DEFFECT_OF_FERTIGATION_ON_FUE_ QUALITY_AND.pdf (accessed on 12 May 2019).

47. Strehle, K.R.; Rösch, P.; Berg, D.; Schulz, H.; Popp, J. Quality control of commercially available essential oils by means of Raman spectroscopy. J. Agric. Food Chem. 2006, 54, 7020-7026. [CrossRef]

48. Gudi, G.; Krähmer, A.; Koudous, I.; Strube, J.; Schulz, H. Infrared and Raman spectroscopic methods for characterization of Taxus baccata L.-Improved taxane isolation by accelerated quality control and process surveillance. Talanta 2015, 143, 42-49. [CrossRef] [PubMed]

49. Gudi, G.; Krähmer, A.; Krüger, H.; Hennig, L.; Schulz, H. Discrimination of Fennel Chemotypes Applying IR and Raman Spectroscopy: Discovery of a New $\gamma$-Asarone Chemotype. J. Agric. Food Chem. 2014, 62, 3537-3547. [CrossRef] [PubMed]

50. Kowal, M.A.; Colzato, L.S.; Hommel, B. Decreased spontaneous eye blink rates in chronic cannabis users: evidence for striatal cannabinoid-dopamine interactions. PLoS ONE 2011, 6, e26662. [CrossRef] [PubMed]

51. Kowal, M.A.; Hazekamp, A.; Colzato, L.S.; van Steenbergen, H.; Hommel, B. Modulation of cognitive and emotional processing by cannabidiol: the role of the anterior cingulate cortex. Front. Hum. Neurosci. 2013, 7 , 147. [CrossRef]

52. Aparna, V.; Dineshkumar, K.; Mohanalakshmi, N.; Velmurugan, D.; Hopper, W. Identification of Natural Compound Inhibitors for Multidrug Efflux Pumps of Escherichia coli and Pseudomonas aeruginosa Using In Silico High-Throughput Virtual Screening and In Vitro Validation. PLoS ONE 2014, 9, e101840. [CrossRef]

53. Jamshidi Aidji, M.; Morlock, G. Effect Directed Analysis of Salvia Officinalis 2014. Available online: https://www.lw-online.de/fileadmin/lwonline/redaktion/pdf-dateien/publikationen/fachpublikationen/ 2017/LWF_2017_-_Morlock.pdf (accessed on 13 May 2019).

54. Cragg, G.M.; Newman, D.J. Natural products: a continuing source of novel drug leads. Biochim. Biophys. Acta 2013, 1830, 3670-3695. [CrossRef]

55. Atanasov, A.G.; Waltenberger, B.; Pferschy-Wenzig, E.-M.; Linder, T.; Wawrosch, C.; Uhrin, P.; Temml, V.; Wang, L.; Schwaiger, S.; Heiss, E.H.; et al. Discovery and resupply of pharmacologically active plant-derived natural products: A review. Biotechnol. Adv. 2015, 33, 1582-1614. [CrossRef]

56. Wright, G.D. Something old, something new: revisiting natural products in antibiotic drug discovery. Can. J. Microbiol. 2014, 60, 147-154. [CrossRef]

57. Newman, D. Screening and identification of novel biologically active natural compounds. F1000Res 2017, 6, 783. [CrossRef] [PubMed]

58. Ramallo, I.A.; Salazar, M.O.; Mendez, L.; Furlan, R.L.E. Chemically Engineered Extracts: Source of Bioactive Compounds. Acc. Chem. Res. 2011, 44, 241-250. [CrossRef]

59. Saxena, M.; Saxena, J.; Nema, R.; Singh, D.; Gubpta, A. Phytochemistry of Medicinal Plants. Phytochem. Med. Plants 2015, 1. Available online: https://www.researchgate.net/publication/284425734_Phytochemistry_of_ Medicinal_Plants/ (accessed on 12 May 2019).

60. Nascimento, G.G.F.; Locatelli, J.; Freitas, P.C.; Silva, G.L. Antibacterial activity of plant extracts and phytochemicals on antibiotic-resistant bacteria. Braz. J. Microbiol. 2000, 31. [CrossRef]

61. Ohene-Agyei, T.; Mowla, R.; Rahman, T.; Venter, H. Phytochemicals increase the antibacterial activity of antibiotics by acting on a drug efflux pump. MicrobiologyOpen 2014, 3, 885-896. [CrossRef] [PubMed]

62. Tzilivakis, J.; Jaggard, K.; Lewis, K.A.; May, M.; Warner, D.J. Environmental impact and economic assessment for UK sugar beet production systems. Agric. Ecosyst. Environ. 2005, 107, 341-358. [CrossRef] 
63. Vercalsteren, A.; Dils, E. Life Cycle Assessment Study of Starch Products for the European Starch Industry Association (AAF): Phase 1 Pretesting. 2012. Available online: https://www.starch.eu/wp-content/uploads/2012/09/201208-Eco-profile-of-starch-products-summary-report.pdf (accessed on 12 May 2019).

64. Diamant Zucker. Daten der Zuckerfabrik Könnern. Available online: https://www.diamant-zucker.de/ unternehmen/standorte/ (accessed on 10 April 2018).

65. Mahesh, V.; Manivannan, B. A study on production process and production efficiency of turmeric cultivation in India. Int. J. Adv. Res. Dev. 2018, 3, 608-611.

66. Avanço, G.B.; Ferreira, F.D.; Bomfim, N.S.; Santos, P.A.d.S.R.d.; Peralta, R.M.; Brugnari, T.; Mallmann, C.A.; Abreu Filho, B.A.d.; Mikcha, J.M.G.; Machinski, M., Jr. Curcuma longa L. essential oil composition, antioxidant effect, and effect on Fusarium verticillioides and fumonisin production. Food Control 2017, 73, 806-813. [CrossRef]

67. Negi, P.S.; Jayaprakasha, G.K.; Jagan Mohan Rao, L.; Sakariah, K.K. Antibacterial Activity of Turmeric Oil: A Byproduct from Curcumin Manufacture. J. Agric. Food Chem. 1999, 47, 4297-4300. [CrossRef]

68. Ammon, H.; Wahl, M. Pharmacology of Curcuma longa. Planta Med. 1991, 51, 1-7. [CrossRef]

69. Panda, A.K.; Chakraborty, D.; Sarkar, I.; Khan, T.; Sa, G. New insights into therapeutic activity and anticancer properties of curcumin. J. Exp. Pharmacol. 2017, 9, 31-45. [CrossRef] [PubMed]

70. DocMorris. Medikamentenpreis. Available online: https://www.docmorris.de/ (accessed on 12 May 2019).

71. Committee for the Common Organisation of Agricultural Markets. Sugar Price Reporting 2018. Available online: https:/ec.europa.eu/agriculture/sites/agriculture/files/market-observatory/sugar/doc/pricereporting_en.pdf (accessed on 12 May 2019).

72. Sixt, M.; Koudous, I.; Strube, J. Process design for integration of extraction, purification and formulation with alternative solvent concepts. Comptes Rendus Chimie 2016, 19, 733-748. [CrossRef]

73. Kassing, M.; Jenelten, U.; Schenk, J.; Strube, J. A New Approach for Process Development of Plant-Based Extraction Processes. Chem. Eng. Technol. 2010, 33, 377-387. [CrossRef]

74. Both, S.; Eggersglüß, J.; Lehnberger, A.; Schulz, T.; Schulze, T.; Strube, J. Optimizing Established Processes like Sugar Extraction from Sugar Beets-Design of Experiments versus Physicochemical Modeling. Chem. Eng. Technol. 2013, 36, 2125-2136. [CrossRef]

75. Uhlenbrock, L.; Sixt, M.; Strube, J. Quality-by-Design (QbD) process evaluation for phytopharmaceuticals on the example of 10-deacetylbaccatin III from yew. Resour.-Effic. Technol. 2017, 3, 137-143. [CrossRef]

76. Bart, H.-J.; Pilz, S. Industrial Scale Natural Products Extraction; Wiley-VCH: Weinheim, Germany, 2011.

77. Fröhlich, H.; Gasser, K.; Gaul, S.; Grützner, T.; Strube, J. Development of Purification Concepts for Nutraceuticals from Algae - Part II: Design of Purification Strategies. Chem. Eng. Technol. 2015, 38, 2035-2044. [CrossRef]

78. Cravotto, G.; Boffa, L.; Genzini, L.; Garella, D. Phytotherapeutics: an evaluation of the potential of 1000 plants. J. Clin. Pharm. Ther. 2010, 35, 11-48. [CrossRef]

79. Both, S.; Chemat, F.; Strube, J. Extraction of polyphenols from black tea-Conventional and ultrasound assisted extraction. Ultrason. Sonochem. 2014, 21, 1030-1034. [CrossRef]

80. Vogelpohl, A. Distillation. The Theory; De Gruyter: Berlin, Germany, 2015.

81. Fröhlich, H.; Gasser, K.; Gaul, S.; Grützner, T.; Strube, J. Development of Purification Concepts for Nutraceuticals from Algae - Part I: Characterization of Emulsifying Components. Chem. Eng. Technol. 2015, 38, 2025-2034. [CrossRef]

82. Mestmäcker, F.; Schmidt, A.; Huter, M.; Sixt, M.; Strube, J. Systematic and Model-Assisted Process Design for the Extraction and Purification of Artemisinin from Artemisia annua L.-Part III: Chromatographic Purification. Processes 2018, 6, 180. [CrossRef]

83. Lucke, M.; Koudous, I.; Sixt, M.; Huter, M.J.; Strube, J. Integrating crystallization with experimental model parameter determination and modeling into conceptual process design for the purification of complex feed mixtures. Chem. Eng. Res. Des. 2018, 133, 264-280. [CrossRef]

84. Rahmani, A.H.; Al Shabrmi, F.M.; Allemailem, K.S.; Aly, S.M.; Khan, M.A. Implications of Green Tea and Its Constituents in the Prevention of Cancer via the Modulation of Cell Signalling Pathway. Biomed. Res. Int. 2015, 2015, 925640. [CrossRef] [PubMed]

85. Fresco, P.; Borges, F.; Diniz, C.; Marques, M.P.M. New insights on the anticancer properties of dietary polyphenols. Med. Res. Rev. 2006, 26, 747-766. [CrossRef] 
86. Kiruthika, N. The Economics of Production of Turmeric In India: A Case Study of Erode District of Tamil Nadujj. J. Innov. Res. Solut. 2013.

87. Zhou, Y.; Zheng, J.; Li, Y.; Xu, D.-P.; Li, S.; Chen, Y.-M.; Li, H.-B. Natural Polyphenols for Prevention and Treatment of Cancer. Nutrients 2016, 8, 515. [CrossRef] [PubMed]

88. Niedzwiecki, A.; Roomi, M.W.; Kalinovsky, T.; Rath, M. Anticancer Efficacy of Polyphenols and Their Combinations. Nutrients 2016, 8, 552. [CrossRef]

89. Chen, D.; Wan, S.B.; Yang, H.; Yuan, J.; Chan, T.H.; Dou, P.D. EGCG green tea polyphenols and prodrugs for human cancer treatment. Adv. Clin. Chem. 2011, 53, 155-177. [PubMed]

90. Wirtschaftliche Vereinigung Zucker (WVZ). Rübenanbau und Zuckererzeugung. Available online: http://www.zuckerverbaende.de/zuckermarkt/zahlen-und-fakten/zuckermarkt-deutschland/ ruebenanbau-zuckererzeugung.html (accessed on 10 April 2018).

91. Ta, C.; Arnason, J. Mini Review of Phytochemicals and Plant Taxa with Activity as Microbial Biofilm and Quorum Sensing Inhibitors. Molecules 2016, 21, 29. [CrossRef]

92. Bundesministerium für Ernährung und Landwirtschaft (BMEL). Roadmap Bioraffinerie. 2012. Available online: https://www.bmel.de/SharedDocs/Downloads/Broschueren/RoadmapBioraffinerien.pdf?_blob= publicationFile (accessed on 10 April 2018).

93. Technische Universität Hamburg-Harburg. Energie aus Biomasse-Neue Wege zur integrierten Bioraffinerie: „BIORAFFINERIE2021“ 2012. Available online: https://bioraffinerie2021.de/wp-content/uploads/2013/09/ BR2021_Abschlussbericht.pdf (accessed on 12 May 2019).

94. Technische Universität Hamburg-Harburg. Energie aus Biomasse-Neue Wege zur integrierten Bioraffinerie (Nachfolgeprojekt): „BIORAFFINERIE2021“ 2015. Available online: http://bioraffinerie2021.de/wp-content/ uploads/2017/07/BR2021_Abschlussbericht-2.pdf (accessed on 12 May 2019).

95. Fraunhofer CBP. Erweiterung der Organosolv-Pilotanlage. Available online: https://www.cbp.fraunhofer.de/ de/forschung/projekte/projekte_rohstoffaufbereitung/erweiterung-organosolv-anlage.html (accessed on 26 September 2018).

96. Landwirtschaftskammer Niedersachsen. Landsortenversuch Stärkekartoffeln. 2015. Available online: https: //m.lwk-niedersachsen.de/?file=25146 (accessed on 13 May 2019).

97. Kaltschmitt, M.; Hartmann, H.; Hofbauer, H. Energie aus Biomasse, 3., aktualisierte Aufl. 2016; Springer Vieweg: Berlin/Heidelberg, Germany, 2016.

98. Graham-Rowe, D. Tank gegen Teller. Spektrum der Wissenschaft. 2012. Available online: https://www. spektrum.de/news/tank-gegen-teller/1142590 (accessed on 13 May 2019).

99. Leonel, M.; Sarmento, S.B.S.; Cereda, M.P. New starches for the food industry: Curcuma longa and Curcuma zedoaria. Carbohydr. Polym. 2003, 54, 385-388. [CrossRef]

100. On the Community Code Relating to Medicinal Products for Human Use. Directive 2001/83/EC. Available online: https://www.ema.europa.eu/en/documents/regulatory-procedural-guideline/directive-2001/83/eceuropean-parliament-council-6-november-2001-community-code-relating-medicinal-products-humanuse_en.pdf (accessed on 12 May 2019).

101. Bundesinstitut für Arzneimittel und Medizinprodukte. Liste der Monographien der E-Kommission (Phyto-Therapie), die im Bundesanzeiger veröffentlicht sind 1994. Available online: https://www.bfarm. de/SharedDocs/Downloads/DE/Arzneimittel/Zulassung/zulassungsarten/besTherap/amPflanz/mono.html (accessed on 12 May 2019).

102. Directive 2004/24/EC Amending, as Regards Traditional Herbal Medicinal Products, Directive 2001/83/EC on the Community Code Relating to Medicinal Products for Human Use. Directive 2004/24/EC. Available online: https://eur-lex.europa.eu/LexUriServ/LexUriServ.do?uri=OJ:L:2004:136:0085:0090:en:PDF (accessed on 12 May 2019).

103. Sixt, M. Entwicklung von Methoden zur systematischen Gesamtprozessentwicklung und Prozessintensivierung von Extraktions- und Trennprozessen zur Gewinnung pflanzlicher Wertkomponenten. Shaker 2018. [CrossRef]

104. Kassing, M.; Jenelten, U.; Schenk, J.; Hänsch, R.; Strube, J. Combination of Rigorous and Statistical Modeling for Process Development of Plant-Based Extractions Based on Mass Balances and Biological Aspects. Chem. Eng. Technol. 2012, 35, 109-132. [CrossRef] 
105. Wirtschaftliche Vereinigung Zucker (WVZ). Standorte des Zuckerrübenanbaus und der Zuckerfabriken. Available online: http://www.zuckerverbaende.de/zuckermarkt/zahlen-und-fakten/zuckermarktdeutschland/standorte.html (accessed on 10 April 2018).

106. Laura Lohmann, L.N.-W. Biogas in NRW-Auswertung der Biogasanlagen-Betreiberdatenbank der Landwirtschaftskammer NRW. Available online: https://www.landwirtschaftskammer.de/landwirtschaft/ technik/biogas/veroeffentlichungen/biogas-in-nrw.htm (accessed on 13 May 2019).

107. Suiker Unie. Besucherinformation und Webseite: Daten zur Zuckerfabrik Anklam. Available online: https://www.suikerunie.de/Produktionsprozess (accessed on 7 August 2018).

108. Fachagentur Nachwachsende Rohstoffe, e.V. Leitfaden Biogas. Von der Gewinnung zur Nutzung, 6., überarb. Aufl.; FNR: Gülzow, Germany, 2013.

109. Bundesnetzagentur. Ergebnisse der Ausschreibung für Biomasse vom 1. September 2017. 2017. Available online: https:/www.bundesnetzagentur.de/DE/Sachgebiete/ElektrizitaetundGas/ Unternehmen_Institutionen/Ausschreibungen/Biomasse/BeendeteAusschreibungen/Gebotstermin_01_09_ 2017/gebotstermin_2017_node.html (accessed on 13 May 2019).

110. Deutscher Bundestag. Gesetz zur Einführung von Ausschreibungen für Strom aus erneuerbaren Energien und $z u$ weiteren Änderungen des Rechts der erneuerbaren Energien. EEG 2017. 2018. Available online: https://www.gesetze-im-internet.de/eeg_2014/EEG_2017.pdf (accessed on 13 May 2019).

111. Deutsches Biomasseforschungszentrum (DBFZ). Hintergrundpapier zur Situation der Bestandsanlagen in den verschiedenen Bundesländern, 2016. Available online: https://www.dbfz.de/fileadmin/user_upload/ Referenzen/Statements/Hintergundpapier_Biomasse_EEG2016.pdf (accessed on 12 May 2019).

112. Bundesministerium für Wirtschaft und Energie (BMWi). Summe aus Börsenstrompreis und EEG-Umlage in Cent/kW von 2011 bis 2018. Available online: https://www.bmwi.de/Redaktion/DE/Infografiken/Energie/ summe-aus-boersenstrompreis-und-eeg-umlage.html (accessed on 12 May 2019).

113. Eurostat. Agriculture, Forestry and Fishery Statistics. 2017. Available online: https://ec.europa.eu/eurostat/ statistics-explained/index.php/Agriculture,_forestry_and_fishery_statistics (accessed on 13 May 2019).

114. Fachagentur Nachwachsende Rohstoffe e.V. (FNR). Bundesministerium für Ernährung und Landwirtschaft (BMEL). In Anbau nachwachsender Rohstoffe in Deutschland 2015-2017; Fachagentur Nachwachsende Rohstoffe e. V. (FNR): Gülzow-Prüzen, Germany, 2018.

115. Bundesnetzagentur (BNetzA). Monitoringbericht 2015. 2015. Available online: https://www. bundesnetzagentur.de/SharedDocs/Downloads/DE/Allgemeines/Bundesnetzagentur/Publikationen/ Berichte/2015/Monitoringbericht_2015_BA.pdf?_blob=publicationFile\&v=4 (accessed on 13 May 2019).

116. Memmler, M.; Lauf, T.; Wolf, K.; Schneider, S. Emissionsbilanz erneuerbarer Energieträger- Bestimmung der vermiedenen Emissionen im Jahr 2016. 2017. Available online: https://www.umweltbundesamt.de/sites/default/ files/medien/1410/publikationen/2017-10-26_climate-change_23-2017_emissionsbilanz-ee-2016.pdf (accessed on 13 May 2019).

117. Bundesanstalt für Agrarwirtschaft. Deckungsbeitrag Kartoffelerzeugung. 2018. Available online: https: //idb.awi.bmlfuw.gv.at/speisekartoffeln.html (accessed on 13 May 2019).

118. Schindler. Erfolgsfaktoren im Kartoffelbau. Nossen. 2011. Available online: http://www.agfdt.de/loads/kt08/ schinabb.pdf (accessed on 13 May 2019).

119. Vetter, A.; Conrad, M.; Biertüpfel, A. Optimierung des Anbauverfahrens für Durchwachsene Silphie (Silphium perfoliatum) als Kofermentpflanze in Biogasanlagen sowie Überführung in die landwirtschaftliche Praxis. Available online: https:/www.db-thueringen.de/servlets/MCRFileNodeServlet/dbt_derivate_00029997/ TLL_Optimierung\%20des\%20Anbauverfahrens\%20fuer\%20Durchwachsende\%20Silphie\%20(Silphium\% 20perfoliatum)\%20als\%20Kofermentpflanze \%20in\%20Biogasanlagen \%20sowie \%20Ueberfuehrung\% 20in\%20die\%20landwirtschaftliche\%20Praxis\%20Abschlussbericht_2010.pdf (accessed on 13 May 2019).

120. Bundesanstalt für Agrarwirtschaft. Deckungsbeitrag Zuckerrüben 2018. Available online: http: //agraroekonomik.at/idb.html (accessed on 13 May 2019).

121. Bayrische Landesanstalt für Landwirtschaft. Deckungsbeitrag Zuckerrüben 2018. Available online: https: //www.lfl.bayern.de/iba/unternehmensfuehrung/088966/index.php (accessed on 13 May 2019).

122. Statistisches Bundesamt. Land-und Forstwirtschaft, Fischerei. Wachstum und Ernte -Feldfrüchte -. Fachserie 3 Reihe 3.2.1, 2018. Available online: https://www.destatis.de/DE/Themen/Branchen-Unternehmen/ Landwirtschaft-Forstwirtschaft-Fischerei/Feldfruechte-Gruenland/_inhalt.html (accessed on 13 May 2019). 
123. Wichtl. Teedrogen und Phytopharmaka. Ein Handbuch für die Praxis auf wissenschaftlicher Grundlage, 5., vollst. überarb. und erw. Aufl.; Wiss. Verl.-Ges: Stuttgart, Germany, 2009.

124. Asensi, M.; Ortega, A.; Mena, S.; Feddi, F.; Estrela, J.M. Natural polyphenols in cancer therapy. Crit. Rev. Clin. Lab. Sci. 2011, 48, 197-216. [CrossRef] [PubMed]

125. Iqbal, J.; Abbasi, B.A.; Mahmood, T.; Kanwal, S.; Ali, B.; Shah, S.A.; Khalil, A.T. Plant-derived anticancer agents: A green anticancer approach. Asian Pacif. J. Trop. Biomed. 2017, 7, 1129-1150. [CrossRef]

126. Priyadarsini, K.I. The chemistry of curcumin: from extraction to therapeutic agent. Molecules 2014, 19, 20091-20112. [CrossRef]

127. Sheik, S.; Chourad, R.; Amarapurkar, S.; Kondarugi, R. Economics of turmeric production under conventional and modern methods in india. Int. J. Commer. Bus. Manag. 2014, 7, 100-104.

128. Christensen, P.; Dysert, L.R. Cost Estimate Classification System: As Applied in Engineering, Procurement, and Construction for the Process Industries, 2016. Available online: https://web.aacei.org/docs/defaultsource/toc/toc_18r-97.pdf?sfvrsn=4 (accessed on 13 May 2019).

129. Peters, M.S.; Timmerhaus, K.D. Plant Design and Economics for Chemical Engineers, 3rd ed.; McGraw-Hill: New York, NY, USA, 1980.

130. Goedecke, R. Fluidverfahrenstechnik; Wiley-VCH: Hoboken, NJ, USA, 2008.

131. Strube, J. Technische Chromatographie: Auslegung, Optimierung, Betrieb und Wirtschaftlichkeit; Zugl.: Dortmund, Univ., Habil.-Schr., 1999, Als Ms. gedr; Shaker: Aachen, Germany, 2000.

132. Zobel, S.; Helling, C.; Ditz, R.; Strube, J. Design and Operation of Continuous Countercurrent Chromatography in Biotechnological Production. Ind. Eng. Chem. Res. 2014, 53, 9169-9185. [CrossRef]

133. Hashimoto, K.; Adachi, S.; Noujima, H.; Ueda, Y. A new process combining adsorption and enzyme reaction for producing higher-fructose syrup. Biotechnol. Bioeng. 1983, 25, 2371-2393. [CrossRef] [PubMed]

134. Meurer, M.; Altenhöner, U.; Strube, J.; Untiedt, A.; Schmidt-Traub, H. Dynamic Simulation of a Simulated-Moving-Bed Chromatographic Reactor for the Inversion of Sucrose. Starch/Stärke 1996, 48, 452-457. [CrossRef]

135. Leistner, J.; Górak, A.; Bäcker, W.; Strube, J. Extraktion als Mittel zur Abwasseraufarbeitung. Chemie Ingenieur Technik 2002, 74, 606. [CrossRef]

136. Helling, C.; Strube, J. Future Processing and Recycling Strategies for Rare Earths. Chemie Ingenieur Technik 2013, 85, 1272-1281. [CrossRef]

137. Schmidt, A.; Strube, J. Application and Fundamentals of Liquid-Liquid Extraction Processes: Purification of Biologicals, Botanicals, and Strategic Metals. Chemical Technol. 2018, 16, 1-52. [CrossRef]

Sample Availability: Samples of the compounds not are available from the authors.

(C) 2019 by the authors. Licensee MDPI, Basel, Switzerland. This article is an open access article distributed under the terms and conditions of the Creative Commons Attribution (CC BY) license (http://creativecommons.org/licenses/by/4.0/). 